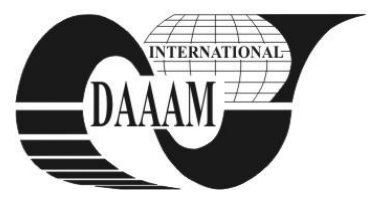

\title{
DIAGNOSTIC ANALYSIS OF SOILS CONTAMINATED WITH OIL AND SALT WATER, STRANDS FOR THEIR REMEDIATION
}

\author{
BUZOIANU, D[aniela] - A[ngela] \& COLOJA, M[ihai] P[ascu]
}

\begin{abstract}
The article presents a number of issues related to soil pollution with oil and salted water. There are presented analyzes that have to be made to determine if a piece of land is affected by oil pollution and salt water and how it affects soil and agricultural production. Also, laboratory results are shown for two polluted areas which were analyzed and for the four soil profiles in the area.B.Finally are presented the improvement works to be executed for the remediation (decontamination) of the two areas.

Keywords: pollution, soil, oil, salted water, diagnosis, improvement works
\end{abstract}

\section{INTRODUCTION}

The quality of the natural environment is one of the most pressing global problems of mankind, because it is not only the preservation of the natural environment, but questioned the very survival of the human species.

In spatial terms, the impact of human activity on the environment can have a planetary impact, regional or local, without identifying through it, the intensity or ecological imbalances, more or less dangerous.

Although signals warning of the effects of particularly serious pollution of air, soil, surface water and groundwater populate oil on health were publicized, demonstrating the danger and the risk of pollution, human memory is selective, subjective and is often used because the claim "the earth shall bear any".

The study was carried out on the surfaces A and B, places where large areas were affected by the phenomenon of pollution with oil and salted water.

The aim of the diagnostic analysis was to specify if these areas are or not affected by oil and salted water pollution, how it negatively affects the soil and agricultural production, but also the necessary ameliorative works to be done for decontamination of the analyzed areas [5].

\section{DIAGNOSTIC ANALISIS OF SOILS CONTAMINATED WITH OIL AND SALTED WATER}

The beam section A, was a failure (breaking) in the pipeline pumping oil. The objective of the experiments was to clarify whether the pipe adjacent land has been affected by oil pollution and salt water and how it influences soil and agricultural production $[2,3]$.
From the polluted area three samples were collected at depths agrochemical average between 0-20 cm, each sample totaling 10 soil samples collected with the agrochemical probe. The soil samples were dried and conditioned in the laboratory, after which the following analyzes were performed $[2,4]$ :

- Soil reaction $(\mathrm{pH})$ - Potentiometric method;

- Soluble salts - method in water extract 1:5;

- $\mathrm{Cl}$ anion content - Mohr method;

- Na ion content - Mohr method;

- Oil residue.

Results of laboratory analyses are shown in Tab. 1:

\begin{tabular}{|c|c|c|c|c|c|c|}
\hline $\begin{array}{c}\text { Sample } \\
\text { name }\end{array}$ & $\begin{array}{c}\text { Depht, } \\
\mathbf{c m}\end{array}$ & $\mathbf{p H}$ & $\begin{array}{c}\mathbf{C l}^{-} \\
\mathbf{m g} / \mathbf{1 0 0 g}\end{array}$ & $\begin{array}{c}\mathbf{N a}^{+} \mathbf{m g} / \\
\mathbf{1 0 0 g}\end{array}$ & $\begin{array}{c}\text { Solu- } \\
\text { ble } \\
\text { salts } \\
\mathbf{\%}\end{array}$ & $\begin{array}{c}\text { Oil } \\
\text { residue } \\
\%\end{array}$ \\
\hline Sample 1 & $0-20$ & 6,01 & 148,8 & 45,6 & 0,43 & 1,19 \\
\hline Sample 2 & $0-20$ & 6,63 & 111,6 & 35,2 & 0,24 & 1,46 \\
\hline Sample 3 & $0-20$ & 6,81 & 834,8 & 73,5 & 1,25 & 2,16 \\
\hline
\end{tabular}

Tab. 1. Laboratory analysis results done for surface A

At B locality it was studied an area of $3361 \mathrm{~m}^{2}$ agricultural land affected by salt water pollution and petroleum products. This area is located in two different surfaces. First with an area of $2000 \mathrm{~m}^{2}$, situated near a disused well and the second with a surface area of 1361 $\mathrm{m}^{2}$, located near highway and railroad.

The objective of the experiments was to clarify whether the $3361 \mathrm{~m} 2$ land has been affected by oil pollution and salt water and how it influences soil and agricultural production [2].

From two contaminated sites were collected 8 agrochemical samples with depth average in the range from 0 to $20 \mathrm{~cm}$ (5 of the first zone and 3 from the second zone), each area meaning a total of 20 soil samples collected as AGROCHIM-type small probe.

\begin{tabular}{|c|c|c|c|}
\hline \multicolumn{2}{|c|}{ Medium texture } & \multicolumn{2}{c|}{ Fine texture } \\
\hline $\begin{array}{c}\text { Soluble salts } \\
\text { pollution } \\
\text { intensity }\end{array}$ & $\begin{array}{c}\text { Limits } \\
\mathrm{mg} / 100 \mathrm{~g} \\
\text { sol }\end{array}$ & $\begin{array}{c}\text { Soluble salts } \\
\text { pollution } \\
\text { intensity }\end{array}$ & $\begin{array}{c}\text { Limits } \\
\mathrm{mg} / 100 \mathrm{~g} \\
\text { sol }\end{array}$ \\
\hline Not salted & $<18$ & Not salted & $<20$ \\
\hline Weak salted & $19-60$ & Weak salted & $21-69$ \\
\hline Medium salted & $61-175$ & Medium salted & $70-200$ \\
\hline Strong salted & $176-360$ & Strong salted & $201-400$ \\
\hline $\begin{array}{c}\text { Very strong } \\
\text { salted }\end{array}$ & $>361$ & $\begin{array}{c}\text { Very strong } \\
\text { salted }\end{array}$ & $>401$ \\
\hline
\end{tabular}

Tab. 2. Soil $\mathrm{Cl}$ ions content 


\begin{tabular}{|c|c|}
\hline Soluble salts pollution intensity & Limits $(\mathrm{mg} / 100 \mathrm{~g} \mathrm{sol})$ \\
\hline Not salted & $<5$ \\
\hline Weak salted & $5-10$ \\
\hline Medium salted & $11-15$ \\
\hline Strong salted & $>16$ \\
\hline Very strong salted & $>25$ \\
\hline
\end{tabular}

Tab. 3. Soil Na ions content.

\begin{tabular}{|c|c|}
\hline Soluble salts pollution intensity & Limits \\
\hline Not salted & $<0.100$ \\
\hline Slab salted & $0.100-0.250$ \\
\hline Moderate salted & $0.260-0.600$ \\
\hline Strong salted & $0.600-1.000$ \\
\hline Very strong salted & $1.000-1.500$ \\
\hline
\end{tabular}

Tab. 3. Soluble salts soil content (\%).

\begin{tabular}{|c|c|}
\hline Oil residue pollution intensity & limits \\
\hline Not polluted & 0 \\
\hline Extremely weak polluted & $0-0.1$ \\
\hline Very weak polluted & $0.1-0.2$ \\
\hline Weak polluted & $0.2-0.4$ \\
\hline Weak-moderate polluted & $0.4-0.5$ \\
\hline Moderate polluted & $0.5-1.0$ \\
\hline Strong polluted & $1.0-5.0$ \\
\hline Very strong polluted & $5.0-10.0$ \\
\hline Extremely strong polluted & $>10$ \\
\hline
\end{tabular}

Tab. 4. Oil residue soil content (\%)

In areas bordering the two polluted areas were collected 2 samples under agrochemical control (sample 6 in the first sample area and 10 in the second area). Also, each area was performed by pedological profile of which were collected six soil samples, corresponding depths: $0-10 \mathrm{~cm}, 10$ to $20 \mathrm{~cm}, 20-40 \mathrm{~cm}, 40-60 \mathrm{~cm}, 60-$ $80 \mathrm{~cm}$.

From the area bordering the two locations were collected six soil control samples (control profile for each area) on the same depths.

\begin{tabular}{|c|c|c|c|c|}
\hline Sample nr. & Soil name & $\begin{array}{c}\mathrm{Na}, \\
\mathrm{mg} / 100 \mathrm{~g} \text { sol. }\end{array}$ & $\begin{array}{c}\text { Soluble } \\
\text { salts, } \%\end{array}$ & $\begin{array}{c}\text { Oil residue, } \\
\%\end{array}$ \\
\hline 1 & sample & 11,0 & 0,039 & 0,17 \\
\hline 2 & sample & 6,8 & 0,028 & 0,09 \\
\hline 3 & sample & 5,2 & 0,023 & 0,06 \\
\hline 4 & sample & 3,3 & 0,021 & 0,06 \\
\hline 5 & sample & 1,3 & 0,023 & 0,05 \\
\hline 6 & Blank & 2,9 & 0,028 & 0,00 \\
\hline 7 & sample & 92,1 & 1,56 & 0,28 \\
\hline 8 & sample & 66,0 & 0,74 & 0,17 \\
\hline 9 & sample & 47,5 & 0,42 & 0,11 \\
\hline 10 & Blank & 10,5 & 0,086 & 0,00 \\
\hline
\end{tabular}

Tab. 7. Results of laboratory tests performed for the two areas

\begin{tabular}{|c|c|c|c|c|c|}
\hline Sample nr. & Denumire sol & $\begin{array}{c}\text { Profil } \\
\text { e nr. }\end{array}$ & $\begin{array}{c}\text { Depht, } \\
\mathrm{cm}\end{array}$ & $\begin{array}{c}\text { Solble } \\
\text { salts, } \\
\%\end{array}$ & $\begin{array}{c}\text { Oil } \\
\text { residue, } \\
\%\end{array}$ \\
\hline 1 & $\begin{array}{c}\text { Polluted soil } \\
\text { evidence }\end{array}$ & 1 & $0-10$ & 0,96 & 0,18 \\
\hline 2 & $\begin{array}{c}\text { Polluted soil } \\
\text { evidence }\end{array}$ & 1 & $10-20$ & 0,21 & 0,11 \\
\hline 3 & $\begin{array}{c}\text { Polluted soil } \\
\text { evidence }\end{array}$ & 1 & $20-40$ & 0,11 & 0,08 \\
\hline 4 & $\begin{array}{c}\text { Polluted soil } \\
\text { evidence }\end{array}$ & 1 & $40-60$ & 0,10 & 0,05 \\
\hline 5 & $\begin{array}{c}\text { Polluted soil } \\
\text { evidence }\end{array}$ & 1 & $60-80$ & 0,08 & 0,05 \\
\hline 6 & $\begin{array}{c}\text { Polluted soil } \\
\text { evedence }\end{array}$ & 1 & $80-100$ & 0,08 & 0,02 \\
\hline 1 & Blank & 2 & $0-10$ & 0,023 & 0,0 \\
\hline 2 & Blank & 2 & $10-20$ & 0,026 & 0,0 \\
\hline 3 & Blank & 2 & $20-40$ & 0,023 & 0,0 \\
\hline 4 & Blank & 2 & $40-60$ & 0,026 & 0,0 \\
\hline 5 & Blank & 2 & $60-80$ & 0,018 & 0,0 \\
\hline 6 & Blank & 2 & $80-100$ & 0,023 & 0,0 \\
\hline
\end{tabular}

\begin{tabular}{|c|c|c|c|c|c|}
\hline 1 & $\begin{array}{c}\text { Polluted soil } \\
\text { evidence }\end{array}$ & 3 & $0-10$ & 0,94 & 0,01 \\
\hline 2 & $\begin{array}{c}\text { Polluted soil } \\
\text { evidence }\end{array}$ & 3 & $10-20$ & 1,15 & 0,09 \\
\hline 3 & $\begin{array}{c}\text { Polluted soil } \\
\text { evidence }\end{array}$ & 3 & $20-40$ & 1,72 & 0,34 \\
\hline 4 & $\begin{array}{c}\text { Polluted soil } \\
\text { evidence }\end{array}$ & 3 & $40-60$ & 2,21 & 0,25 \\
\hline 5 & $\begin{array}{c}\text { Polluted soil } \\
\text { evedence }\end{array}$ & 3 & $60-80$ & 2,83 & 0,18 \\
\hline 6 & $\begin{array}{c}\text { Polluted soil } \\
\text { evidence }\end{array}$ & 3 & $80-100$ & 2,89 & 0,1 \\
\hline 1 & Blank & 4 & $0-10$ & 0,125 & 0,0 \\
\hline 2 & Blank & 4 & $10-20$ & 0,112 & 0,0 \\
\hline 3 & Blank & 4 & $20-40$ & 0,260 & 0,0 \\
\hline 4 & Blank & 4 & $40-60$ & 0,068 & 0,0 \\
\hline 5 & Blank & 4 & $60-80$ & 0,039 & 0,0 \\
\hline 6 & Blank & 4 & $80-100$ & 0,039 & 0,0 \\
\hline
\end{tabular}

Tab. 5. The results of laboratory tests performed for the two contaminated sites and four soil profiles

\section{DIAGNOSIS RESULTS}

For A zone, comparing the data presented in Tab, with the interpretation of chemical values in Tabs $2-6$, we can go to the following conclusions:

\section{Agrochemical sample number 1}

- Reaction is slightly acid soil $(\mathrm{pH}=6.01)$;

- $\mathrm{Cl}$ ion content - moderate soil salted $(148.8 \mathrm{mg} / 100 \mathrm{~g}$ soil);

- The content of $\mathrm{Na}$ ions - strong ground salted (45.6 $\mathrm{mg} / 100 \mathrm{~g}$ soil);

- The content of soluble salts - soil moderately salted $(0.43 \%)$;

- Oil residue-soil heavily polluted (1.19\%).

Agrochemical sample number 2

- Reaction is slightly acid soil $(\mathrm{pH}=6.55)$;

- $\mathrm{Cl}$ ion content - moderate soil salted (111.6 mg/100g soil);

- The content of Na ions - strong ground salted (35.2 $\mathrm{mg} / 100 \mathrm{~g}$ soil);

- The content of soluble salts - soil salted low (0.24\%);

- Dry oil - heavily polluted soil (1.46\%).

Agrochemical sample number 3

- Reaction is slightly acid soil $(\mathrm{pH}=6.83)$;

- $\mathrm{Cl}$ ion content - very strong ground salted (834.8 $\mathrm{mg} / 100 \mathrm{~g}$ soil);

- The content of $\mathrm{Na}$ ions - strong ground salted (73.5 $\mathrm{mg} / 100 \mathrm{~g}$ soil);

- soluble salt content - very strong ground salted $(1.26 \%)$;

- Dry oil - heavily polluted soil (2.16\%).

From the analysis and interpretation of results for A zone, we can see that the entire area is fully affected by salt water and oil pollution.

Agrochemical sample number 1 is moderately saline soluble salts and chloride ions very strongly saline with sod-Soluble salts content - not salted $(0.039 \%)$; $\mathrm{Na}$ ions and heavily polluted with oil residue.

Agrochemical sample number 2 is poorly soluble salt saline, moderately saline with chloride ions very strongly 
saline with sodium ions, pollution from oil residue being, as in the previous proof, strong.

Agrochemical sample number 3 is very strong saline soluble salts, sodium ions and chloride ions; waste oil pollution is still strong.

Study results, show a high degree of pollution and salt water residue of oil pipeline pumping nearby area, high exceeding recorded for indicators analyzed, the most restrictive factors as sodium ions and residual oil.

Due to the presence of soluble salts and oil residue, soil changes its natural qualities. Their presence causes the extracellular osmotic pressure of the soil, the intracellular going beyond the plant, so plants cannot absorb water from the soil.

For B zone, comparing the data presented in Tab. 7 limits the interpretation of chemical values in Tab. 2. - 6 . the following conclusions:

\section{Polluted area number 1 - area $2000 \mathrm{~m}^{2}$.}

Agrochemical sample number 1 has the following characteristics:

- Content of sodium ions $(\mathrm{Na}+)$ - medium (11.0 $\mathrm{mg} / 100 \mathrm{~g}$ soil);

- Residue oil - very low polluted $(0.17 \%)$.

Agrochemical sample considered polluted from area number $2\left(1381 \mathrm{~m}^{2}\right)$ has the following features:

- Soluble salts content - not salted $(0.028 \%)$;

- Ion content $(\mathrm{Na}+)$ - small $(6.8 \mathrm{mg} / 100 \mathrm{~g}$ soil $)$;

- Residue oil - polluted very weak (0.09\%).

Agrochemical sample number 3 considered polluted area has the following characteristics:

- Soluble salts content - not salted $(0.023 \%)$;

- Ion content $(\mathrm{Na}+)$ - small $(5.2 \mathrm{mg} / 100 \mathrm{~g}$ soil $)$;

- Residue oil - polluted very weak (0.06\%).

Agrochemical sample number 4 considered polluted area has following features:

- Soluble salts content - not salted $(0.02 \%)$;

- Ion content $(\mathrm{Na}+)$ - not salted $(3.3 \mathrm{mg} / 100 \mathrm{~g}$ soil);

- Residue oil - polluted very weak $(0.06 \%)$.

Agrochemical sample considered polluted area number 5 has the following characteristics:

- Soluble salts content - not salted $(0.023 \%)$;

- Ion content $(\mathrm{Na}+)$ - not salted $(1.3 \mathrm{mg} / 100 \mathrm{~g}$ soil $)$;

- Residue oil - polluted very weak $(0.05 \%)$.

Agrochemical sample number 6 (blank) considered polluted area adjacent area has the following characteristics:

- Soluble salts content - not salted $(0.028 \%)$;

- Ion content $(\mathrm{Na}+)$ - not salted $(2.9 \mathrm{mg} / 100 \mathrm{~g}$ soil $)$;

- Residue oil - absent.

Pedological profile considered polluted area number 1 has the following characteristics:

- The content of soluble salts - great for the first $10 \mathrm{~cm}$ $(0.96 \%)$, than not salted between $10-60 \mathrm{~cm}$.
- Residue oil - very low polluted up to $20 \mathrm{~cm}(0.11$ $0.18 \%)$ and very low pollution below (0.02 to $0.08 \%$ ).

Pedological profile number 2 (profile blank) considered polluted area adjacent area has the following characteristics:

- Soluble salts content - all profiles not salted (0.018 to $0.026 \%$ );

- Residue oil - absent throughout the profile.

- Polluted area number 2 - area $1361 \mathrm{~m}^{2}$.

Agrochemical sample number 7 considered polluted area has the following characteristics:

- Soluble salts content - very large $(1.56 \%)$;

- Ion content $(\mathrm{Na}+)$ - very high $(92.1 \mathrm{mg} / 100 \mathrm{~g}$ soil $)$;

- Residue oil - polluted low (0.28\%).

Agrochemical sample number 8 considered polluted area has the following characteristics:

- Soluble salts content - large (0.74\%);

- Ion content $(\mathrm{Na}+)$ - very high $(66.0 \mathrm{mg} / 100 \mathrm{~g}$ soil $)$;

- Residue oil - very low polluted $(0.17 \%)$.

Agrochemical sample considered polluted area number 9 has the following characteristics:

- Soluble salts content - medium $(0.42 \%)$;

- Ion content $(\mathrm{Na}+)$ - very high $(47.5 \mathrm{mg} / 100 \mathrm{~g}$ soil $)$;

- Residue oil - very low polluted $(0.11 \%)$.

Agrochemical sample number 10 (blank) considered polluted area adjacent area has the following characteristics:

- Soluble salts content - not salted $(0.086 \%)$;

- Ion content $(\mathrm{Na}+)$ - small-moderate $(10.5 \mathrm{mg} / 100 \mathrm{~g}$ soil);

- Residue oil - absent.

Pedological profile considered polluted area number 3 has the following features:

- Soluble salts content - great for the first $10 \mathrm{~cm}$ $(0.94 \%)$ and very high below (1.15 to $2.89 \%)$;

- Residue oil - polluted very weak in the first $20 \mathrm{~cm}$ (0.01 to $0.09 \%)$, slightly polluted between $20-60 \mathrm{~cm}$ $(0.25-0.34 \%)$ and weakly polluted below $(0.10$ to 0 , $18 \%)$.

Pedological profile number 4 (witness profile) from adjacent area considered polluted area has the following characteristics:

- Soluble salts content - than the first $20 \mathrm{~cm}(0.112$ to $0.125 \%)$, average between $20-40 \mathrm{~cm}(0.260 \%)$ and not salted below ( 0.039 to $0.068 \%)$;

- Residue oil - absent throughout the profile.

From the analysis and interpretation of results can be observed that the presence of salt water soil attributes were modified, productive capacity is very much decreased.

\section{Zone 1 - area $2000 m^{2}$.}

If soluble salts, pedological profile location number 1 of $2000 \mathrm{~m}^{2}$ in area considered polluted values are above 
the $0.100 \%$, which indicates that the soil is polluted. More precisely, the pollution is high in the first $10 \mathrm{~cm}$, slightly between $10-60 \mathrm{~cm}$ and at depths greater than 60 $\mathrm{cm}$ soil is not salted. We note that the soil profile" salts are not in place "; they go up and down depending on the ground-water and rainfall. Presence of soluble salts causes the extracellular osmotic pressure of soil, surpassed the intracellular the plant, so plants cannot absorb water from the soil.

At the same profile, pedological number 1 have a very low pollution with waste oil to a depth of $20 \mathrm{~cm}$ and very low at depths greater than $20 \mathrm{~cm}$. Pedological profile 2, considered a witness for location 1 is not polluted with salt water, or with oil residue.

All 5 samples taken from the middle agro-chemical considered polluted location soluble salts, have values below $0.100 \%$, which indicates that we have not salt pollution. There are, however, very low oil pollution from agrochemical sample 1 and very weak in samples 2 , 3, 4, and 5. Results show, one sodium ion content is moderate in samples 2 and 3 is small, samples 4 and 5 being polluted with sodium ions. Six agro- chemical sample taken from polluted area adjacent area in one location has not exceeded normal values in any of the analyzes and thus uninfected salt water or oil.

\section{Zone 2 - area $1361 m^{2}$.}

Pedological profile number 3 made in the area considered polluted site 2 , has exceeded normal values both soluble salts and the oil residue. If salt concentration is high in the first $10 \mathrm{~cm}$, making it very depths of over $10 \mathrm{~cm}$. Residual oil content is extremely low up to 20 $\mathrm{cm}$, low between $20-60 \mathrm{~cm}$ and very low at depths greater than $60 \mathrm{~cm}$.

Pedological profile number 4 , considered a witness for location 2, also shows pollution soluble salts to a depth of $40 \mathrm{~cm}$. Samples agrochemical environments polluted area location 2 are moderate to very heavily polluted with salt water, the sodium ion content is also very high in all 3 samples. Proven oil residue is weak and very weak in samples 8 and 9 .

Agrochemical sample 10, considered a witness for location 2 has a low pollution - moderate sodium ions. The high percentage of sodium in the soil produces unfavorable plant growth following features:

- Wet soil mass into a muddy, sticky, impervious to water and air;

- Dry soil forms a hard crust and crack, forming large lumps established;

- Reduced hydraulic conductivity, thereby preventing water infiltration into the soil;

- Water is retained by powerful forces changing the root system of plants;

- Plants have low growth may even lead to its shutdown;

- Reduced microbiological activity in the soil;

- They cause decalcification and loss of soil organic matter.

Values obtained from analyzes conducted and that the surface of $3361 \mathrm{~m}^{2}$ is totally polluted with oil residue soluble salts and values content of soluble salts and sodium ions greatly exceed the maximum allowed levels.

\section{CONCLUSION}

The most suiTab. method for A zone is stripping zone is affected by pollution layer, preferably over $0.7 \mathrm{~m}$ deep, followed by installing a filter layer to prevent capillary rise of salts and cover with a layer of fertile soil, good for growth and crop development [1].

For B zone, decontamination of the analyzed areas, following developments and improvement works are proposed [1]:

- Overburden layer as a high salt content up to depths of $100120 \mathrm{~cm}$ if groundwater permits, and installing a filter layer to prevent capillary rise of salts followed binding fertile land.

- Deep cleaning of soluble salts with large amounts of water, depending on soil texture (1000 $1200 \mathrm{~m} 3$ for medium texture).

- Artificial drainage works to collect wash water rich in salts and their disposal.

Of the three solutions mentioned above, the only solution that can be applied when the ground is affected by pollution, scraping salt layer cover lying fertile land [1]. Even this work is quite difficult to implement, especially for location 2, soluble salts pollution down to the deep sea, the content is very high at a depth of 100 $\mathrm{cm}(2.89 \%)$.

High concentration of salts in the profile is due to the vertical infiltration of salt water, which could reach the groundwater.

Not recommended, due to lack of drainage, works artificial channel, to take large quantities of water needed money salts, there is a danger salt water pollution and land surrounding the lateral infiltration.

Also, deep cleaning of soluble salts with large amounts of water is not recommended, especially since the land is considered very close to a probe oil extraction.

A method that also could be applied is decontamination of soil through bioremediation techniques. It can be a subject for a new study.

\section{REFERENCES}

[1] Neag.Ghe.,(1997), Remediating soils and groundwater (Depoluarea solurilor si apelor subterane), Editura Casa Cartii de Stiinta,Cluj-Napoca

[2] Toti, M., Dumitru, M., Constantin, C.,(1999), Oil pollution of the soil and salt water from Romania - (Poluarea cu petrol și apă sărată a solurilor din Romania), Editura Riso Print, Cluj-Napoca

[3] Toti, M., Rauta,C., Dumitru, M., Capitanu, G. E., Damian, M., (1992), Distribution of the main types of pollution with oil residues and salt water in Romania (Distribuţia principalelor tipuri de poluare cu reziduuri petroliere şi apă sărată din Romania), Analele ICPA nr.52, Bucureşti

[4] *** SR ISO 14014 Standards, Preliminary guide to the analysis of the environment,(Ghid pentru analiza preliminara de mediu), 1999

[5] *** Soil status in Romania,(Starea solurilor din România), Ministerul Mediului şi Gospodăririi Apelor, 2003-2007 